НАУКОВИЙ ВІСНИК

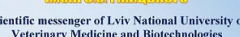

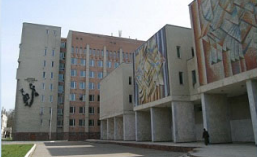

Науковий вісник Аьвівського національного університету ветеринарної медицини та біотехнологій імені С.3. Гжицького. Серія: Ветеринарні науки

Scientific Messenger of Lviv National University of Veterinary Medicine and Biotechnologies. Series: Veterinary sciences

UDC 636.4.09:612.017:615.326

\title{
Immune status of piglets after administration of Iron(IV) clatrochelate to pregnant sows
}

\author{
V. B. Dukhnitskyi, I. M. Derkach, S. S. Derkach \\ National University of Life and Environmental Sciences of Ukraine, Kyiv, Ukraine
}

Article info

Received 29.06.2021

Received in revised form 29.07.2021

Accepted 30.07.2021

The National University of Life and Environmental Sciences of Ukraine, Heroyiv Oborony Str., 15 , Kyiv, 03041, Ukraine.

Tel: $+38-066-772-41-94$

E-mail:irina1215@ukr.net

Dukhnitskyi, V. B., Derkach, I. M., \& Derkach, S. S. (2021). Immune status of piglets after administration of Iron(IV) clatrochelate to pregnant sows. Scientific Messenger of Lviv National University of Veterinary Medicine and Biotechnologies. Series: Veterinary sciences, 23(103), 35 42. doi: $10.32718 /$ nvlvet10306

The degree of the physiological development of the body of piglets in the first months after birth is important because, during this period, there is an active formation of many organism systems, including those that provide homeostasis. The resistance of piglets to diseases of various etiologies during life depends on the formation of the immune system. Our study aimed to assess the immune status of piglets born to sows that received injections of solutions of Iron(IV) clatrochelate and cyanocobalamin during pregnancy. To achieve this goal, two groups of newborn piglets-analogs were formed during their retention with suckling sows - control and experimental, 15 animals each. Piglets from 5 sows (3 from each) were injected into the experimental group, which were injected $10 \mathrm{ml}$ of $10 \%$ solution of Iron(IV) clatrochelate and cyanocobalamin solution twice during pregnancy (14 and 7 days before the expected farrowing) intramuscularly. Piglets of the control group, according to the traditional scheme of prevention of iron deficiency anemia on the second day of life, were administered irondextran drug uniferon (200 mg of iron (III) per injection). Piglets and sows were observed for two months; for studies of the content of immunoglobulins in the piglets' serum, the blood samples were taken at 1, 5, 12, and 30 days of life. During the experiment, the indicators of the content of immunoglobulins of classes $G, A, M$ in the serum of piglets of the experimental group and the dynamics of their changes within 30 days after birth did not differ from the control. Two injections of $10 \%$ solution of Iron(IV) clatrochelate in a dose of $10 \mathrm{ml}$ in combination with cyanocobalamin injections at a dose of $500 \mathrm{mg}$ of active substance to pregnant sows 14 and 7 days before the expected farrowing did not adversely affect the immune status of newborn piglets. Furthermore, this has a high prophylactic effect against iron deficiency anemia.

Key words: anemia, clatrochelate, colostrum, cyanocobalamin immunoglobulins, iron, piglets, sows, serum.

\section{Імунний статус поросят за застосування клатрохелату Феруму(IV) вагітним свиноматкам}

\author{
В. Б. Духницький, I. М. Деркач, С. С. Деркач
}

Національний університет біоресурсів і природокористування Украӥни, м. Київ, Украӥна

Ступінь фізіологічного розвитку організму поросят у перші місяці після народження має важливе значення, оскільки упродовж цььго періоду відбувається активне формування багатьох систем організму, зокрема й тих, щяо забезпечують гомеостаз. Стійкість поросят до захворювань різної етіологї упродовж життя залежать саме від становлення імунобіологічної системи. Метою нашої роботи було оцінити імунний статус організму поросят, народжених від свиноматок, яким у період вагітності застосовували ін'єкції розчинів клатрохелату Феруму(IV) і иіанокобаламіну. Для виконання поставленої мети було сформовано 2 групи новонароджених поросят-аналогів у період їх утримання зі свиноматками на підсосі - контрольна та дослідна, по 15 тварин у кожній. У дослідну групу були відібрані поросята від 5-ти свиноматок (по 3 від кожної), яким в період вагітності 
двічі (за 14 та 7 діб до очікуваного опоросу) внутрішньом'язово вводили по 10 мл 10 \% розчину клатрохелату Феруму(IV) та розчин ціанокобаламіну. Поросятам контрольної групи за традиційною схемою профілактики ферумодефіцитної анемії на другу добу життя вводили ферумодекстрановий препарат юніферон (200 мг Феруму(III) на одне введення). Протягом 2 місяців за поросятами та свиноматками здійснювали спостереження; для досліджень вмісту імуноглобулінів у сироватці крові поросят відбирали зразки крові на 1, 5, 12 та 30 доби життя. Упродовж досліду показники вмісту імуноглобулінів класів $G$, A, M у сироватці крові поросят дослідної групи та динаміка їх змін протягом 30 діб після народження майже не відрізнялась від контролю. Дворазова ін 'єкція поросним свиноматкам 10 \% розчину клатрохелату Феруму(IV) в дозі 10 мл у поєднанні з ін'єкціями изіанокобаламіну у дозі 500 мкг діючої речовини за 14 та 7 діб до передбачуваного опоросу не впливала негативно на імунний статус новонароджених поросят, забезпечуючи при ияьому високий профілактичний ефект щзодо ферумодефіцитної анемії.

Ключові слова: анемія, імуноглобуліни, клатрохелат, молозиво, поросята, свиноматки, сироватка крові, Ферум, ичіанокобаламін.

\section{Вступ}

Імунітет є важливою складовою збереження імунологічної індивідуальності, механізмом підтримки імунологічного гомеостазу організму за допомогою неспецифічних і специфічних клітинних та гуморальних факторів.

Як відомо, розвиток імунної системи в організмі поросят розпочинається ще 3 ранніх періодів гестації, адже в селезінці та тимусі плода перші В- та Тклітини з'являються у 30-40-добовому віці. Вже наприкінці гестації їхня кількість поступово збільшується і плід може спричинити імунну відповідь на введення антигенів. Водночас епітеліохоріальна плацента $є$ бар'єром для проходження антитіл та імунних клітин від свиноматки до плоду, тому від надходження 3 молозивом/молоком материнських антитіл залежить збереженість новонароджених поросят. Загалом імунна система, як і інші системи організму тварини, впродовж періоду онтогенезу підлягає значним перебудовам, які зумовлюють зміну її структури та характеру діяльності у майбутньому (Koliakov, 1986; Voronyn et al., 2002; Roit et al., 2006; Kryshtoforova et al., 2007; Salyha, 2009).

Для об’єктивної оцінки стану захисних сил організму необхідною є інформація про оптимальний рівень показників, що характеризують клітинну і гуморальну ланки, а також факторів, які впливають на формування імунобіологічної системи організму в процесі його життєдіяльності. Важлива роль у цьому разі відводиться рівню фізіологічного розвитку організму поросят у перші місяці життя, коли відбувається активне формування багатьох систем організму, що забезпечують гомеостаз. 3 іншого боку, життєздатність та стійкість поросят до захворювань різної етіології протягом цього періоду залежать саме від становлення імунобіологічної системи (Zharov, 2003; Havrylin et al., 2005; Hryhorev, 2006; Panikar et al., 2015; Todoriuk et al., 2018; Martyshuk et al., 2019; 2020).

Варто зауважити, що свині порівняно з тваринами інших видів мають високі показники кількості імуноглобулінів усіх класів. Згідно з результатами досліджень деяких авторів, у сироватці крові свиней імуноглобуліни класу А становлять 15-20 \% усіх імуноглобулінів, імуноглобуліни класу $\mathrm{G}$ становлять 70-80 \%, імуноглобуліни класу $\mathrm{M}-10$ \% відповідно (Bland et al., 2003; Butler et al., 2009). До начисленніших Ig класу $\mathrm{G}$ належать антитіла проти більшості антигенів різного походження; вони забезпечують захист від широкого спектру чужорідних агентів: бактерій, віру- сів, токсинів, а з імуноглобулінами класу А запобігають контамінації слизової оболонки кишечнику вірулентними бактеріями. Ig класу А мають дві форми сироваткову та секреторну; остання відіграє важливу роль у формуванні механізмів місцевої резистентності, протидіє масовому надходженню антигенів, перешкоджає прикріпленню бактерій до епітеліоцитів, нейтралізує ентеротоксини, сприяє фагоцитозу. Імуноглобуліни класу М слугують рецепторами В-клітин, 3'являються першими у крові за первинної імунної відповіді, разом імуноглобулінами класу А беруть участь у місцевому імунітеті (Panikar et al., 2015). Роль імуноглобулінів класів Е та D є менш вивченою.

Показники кількості антитіл різних класів у сироватці крові поросят мають суттєві розбіжності у різних авторів, що своєю чергою ускладнює аналіз цифрових результатів. За результатами досліджень, проведених Панікаром I. I. (Panikar et al., 2013; 2014), аналіз загальної кількості імуноглобулінів вказує, що найбільшим цей показник (4,38 мг/мл) є в поросят у перші години життя, після чого спостерігається його зниження до кінця першого тижня життя: 3,56 мг/мл на першу добу та 2,41 мг/мл - на 7 добу. До 29добового віку даний показник зростає до 3,46 мг/мл. За даними Масьянова Ю. (Mas'janov, 1992), кількість імуноглобулінів усіх класів поступово зменшується впродовж усього місяця, а згідно з даними Кадирова C. (Kadyrov, 1985), така динаміка характерна лише для Ig класу G, і у цьому випадку мінімальні значення Ig класу М зареєстровані на 10 добу, а Ig класу A - на 30 добу, після чого кількість імуноглобулінів усіх класів поступово збільшується.

Ряд вчених (Maslianko et al., 2000; 2002; 2004; Meier \& Kharvy, 2007; Salyha, 2009; Ratskyi et al., 2010) вважають, що для новонароджених тварин характерна змінна гіпогаммаглобулінемія, що зумовлено недостатньою функціональною здатністю імунної системи молодняку до синтезу власних антитіл, яка триває упродовж 1-2 місяців до завершення розвитку імунної системи. Доведено, що найвищий рівень $\gamma$ глобулінів у сироватці крові поросят спостерігається через 6-12 год після споживання молозива. Значні коливання кількості антитіл класу $G$ пов'язують 3 кількістю цих антитіл у молозиві.

Варто зазначити, що забезпечення споживання молозива новонародженою твариною у перші години після народження має дуже важливе значення, адже, крім імуноглобулінів, з молозивом свиноматки в організм поросят надходять Т і В-лімфоцити, нейтрофіли та фагоцити. Також у молозиві містяться вітаміни, 
мікроелементи, мінерали, що є важливими факторами росту для потомства (Tytarenko, 2020).

Перший місяць після народження вважають одним 3 найкритичніших періодів життя поросят, адже на 23 тиждень у них суттєво послаблюється загальний фізіологічний стан та резистентність. У цей період поросята є особливо чутливими до нестачі в їхньому організмі Феруму. Недостатня увага до дефіциту життєво важливого мікроелементу чи невчасна профілактика цього провокує розвиток ферумодефіцитної анемії, яку вважають найбільш поширеною незаразною хворобою поросят. Нестача мікроелементу спричиняє пригнічення кровотворення і розлади ензимних систем організму, наслідком чого $є$ змішана гіпоксія, негативні метаболічні і функціональні зміни в органах, тканинах та клітинах організму (Antipov \& Zharov, 2013; Ganz, 2013; Gasanov et al., 2020). У цьому разі в крові зменшується загальна кількість лейкоцитів, популяції Т і В лімфоцитів, нейтрофілів, моноцитів, гальмується фагоцитарна активність та знижується індекс фагоцитозу, елімінуюча здатність крові, а також вміст протеїну загального та імуноглобуліну класу G (Karput' \& Nikoladze, 2001; Levchenko et al., 2012). Встановлено, що від анемії може загинути до чотирьох поросят у гнізді. При цьому варто згадати про значні витрати на лікування хворих тварин та профілактику різних вторинних патологій, зокрема вторинного імунодефіциту, а також про зниження рентабельності в результаті уповільнених темпів росту, погіршення племінних якостей тварин тощо.

Загалом сучасний фармацевтичний ринок в Україні забезпечений протианемічними препаратами, але вони мають ряд недоліків, тому розробка нових ефективним ферумовмісних лікарських засобів 3 метою профілактики ферумодефіцитної анемії поросят не втрачає актуальності й нині. 3 цією метою нами проведено ряд необхідних доклінічних та клінічних досліджень нової клатрохелатної сполуки Феруму в рідкісній валентності (Dukhnitsky et al., 2018; 2019; 2020; Derkach, 2021), про яку вперше повідомили Tomyn et al. (2017). На основі результатів дослідження протианемічної ефективності даного комплексу було запропоновано нову схему профілактики, яка заснована на застосуванні препарату вагітним свиноматкам у період вагітності. Дворазова ін'єкція поросним свиноматкам $10 \%$ розчину клатрохелату Феруму(IV) за 14 та 7 діб до передбачуваного опоросу забезпечувала профілактичний ефект щодо ферумоефіцитної анемії у народжених від них поросят (Dukhnitsky et al., 2021; Derkach, 2021). Наступним етапом наших досліджень було вивчення протианемічної ефективності комбінації ін'єкцій розчину клатрохелату Феруму(IV) та розчину ціанокобаламіну, за тих же умов - лікарські засоби вводились не новонародженим поросятам згідно з традиційними схемами профілактики ферумодефіцитної анемії, а свиноматкам у період вагітності.

Як відомо, ціанокобаламін досить часто входить до складу протианемічних препаратів; він $є$ антианемічним вітаміном, необхідним для нормального кровотворення, проявляє метаболічну та гемопоетичну функцію. В організмі (переважно в печінці) перетворюється у коферментну форму вітаміну $\mathrm{B}_{12}$ - аденозилкобаламін, або кобамамід, який має високу біологічну активність.

Результати досліджень динаміки маси тіла поросят, морфологічних показників крові та біохімічних показників сироватки крові підтверджують ефективність такої схеми профілактики, але залишається невивченим стан імунного захисту поросят, народжених від свиноматок, яким ін'єкували вищезазначені препарати.

Мета роботи - оцінити імунний статус організму поросят, народжених від свиноматок, яким у період вагітності застосовували ін'єкції розчинів клатрохелату Феруму(IV) і ціанокобаламіну.

\section{Матеріл і методи досліджень}

Усі маніпуляції з тваринами проводили відповідно до Європейської конвенції про захист хребетних тварин, які використовуються для експериментальних $\mathrm{i}$ наукових цілей (Official Journal of the European Union L276/33, 2010).

Для виконання поставленої мети було сформовано 2 групи новонароджених поросят-аналогів (гібриди порід ландрас та велика біла) у період їхнього утримання зі свиноматками на підсосі - контрольна та дослідна, по 15 тварин у кожній. У дослідну групу були відібрані поросята від 5 свиноматок (по 3 від кожної), яким в період вагітності двічі (за 14 та 7 діб до очікуваного опоросу) внутрішньом'язово вводили по 10 мл $10 \%$ розчину клатрохелату Феруму(IV) та розчин ціанокобаламіну (у дозі для свиноматок, рекомендованій офіційними інструкціями, - 3 розрахунку по 500 мкг діючої речовини на одне введення). Поросятам контрольної групи за традиційною схемою профілактики ферумодефіцитної анемії на другу добу життя вводили ферумдекстрановий препарат юніферон у дозі 1 мл для тварини (200 мг Феруму(III) на одне введення).

Діючою речовиною препарату, що застосовували свиноматкам, є Ферум у рідкісній валентності IV та у формі клатрохелату - це макробіциклічний комплекс, у якому іон металу «упакований» у нанокапсулу, яка перешкоджає взаємодії з переважною більшістю реагентів, зокрема біолігандами, а також екранує метал від інших факторів навколишнього середовища. Для розчинення порошку клатрохелату Феруму(IV) було використано розчинник реополіглюкін, що є плазмозамінним колоїдним розчином декстрану (полімеру глюкози).

Протягом 2 місяців за поросятами та свиноматками здійснювали спостереження; для досліджень вмісту імуноглобулінів у сироватці крові поросят відбирали зразки крові на 1, 5, 12 та 30 доби життя.

\section{Результати та їх обговорення}

Упродовж науково-виробничого досліду не виявлено народження мертвих поросят та жодних клінічних ознак анемії: блідість слизових оболонок (з жов- 
туватим відтінком), скуйовдженість щетини, сухість чи зморщення шкіри поросят. Також не спостерігалося прискорення пульсу та ритму дихання у тварин, відставання у рості, розладів травлення чи малорухливості, що $є$ характерним для прояву анеміі. Побічних реакцій на введення препаратів не виявлено. Поросята дослідної групи були активнішими, ніж поросята контрольної групи.

Вміст імуноглобулінів у сироватці крові поросят, який визначали на $1,5,12$ та 30 доби життя тварин, наведено у таблицях 1-3.

\section{Таблиця 1}

Динаміка вмісту імуноглобулінів класу $\mathrm{G}$ у сироватці крові поросят, г/л $(\mathrm{M} \pm \mathrm{m}, \mathrm{n}=15)$

\begin{tabular}{ccc}
\hline Biк поросят, & \multicolumn{2}{c}{ Група поросят } \\
\cline { 2 - 3 } діб & I контрольна & II дослідна \\
\hline 1 & $0,3 \pm 0,01$ & $0,3 \pm 0,01$ \\
5 & $5,3 \pm 0,15$ & $5,4 \pm 0,14^{*}$ \\
12 & $2,4 \pm 0,14$ & $2,6 \pm 0,19^{*}$ \\
30 & $2,0 \pm 0,07$ & $2,1 \pm 0,06$ \\
\hline
\end{tabular}

Примітка: ступінь вірогідності - * - P <0,05 порівняно 3 показником у поросят контрольної групи

Вміст імуноглобулінів класу $\mathrm{G}$ у сироватці крові поросят дослідної групи майже не відрізнявся від контролю. Загалом на першу добу життя до отримання молозива кількість імуноглобулінів цього класу була низькою у сироватці крові поросят обох груп. На 5 добу цей показник значно зростав, що можна пояснити тим, що поросята отримували імуноглобуліни з материнським молозивом/молоком, але до 30-ї доби знову ж таки знижувався. Отримані нами результати суперечать даним Штерцль зі співавт. (Shtertsl et al., 1992), що вказують на відсутність Ig класу G у сироватці крові поросят, які не отримували молозива, але підтверджують дані більшості дослідників. Так, Лаптенок B. (Laptenok, 1986) довів наявність Ig класу G у плодів свиней до народження та у новонароджених поросят, причому кількість імуноглобулінів після отримання молозива збільшувалася у 7 разів, а далі, впродовж першого місяця життя, знижувалася. Панкар I. виділяє так званий період “провалу” в кінці першого тижня життя поросят, а саме зменшення кількості даного виду імуноглобулінів у сироватці крові майже в 2,6 раза (3 $3,11 \pm 0,01$ до $1,19 \pm 0,02$ мг/мл). У цей час запаси імуноглобулінів класу $\mathrm{G}$ в організмі поросят, ймовірно, зменшуються, а сам новонароджений організм ще не в змозі виробляти достатню кількість даного виду імуноглобулінів. Проте ми не підтримуємо результати досліджень Панікара I. (Panikar et al., 2013), які показують високий рівень Ig класу $\mathrm{G}(3,11 \pm 0,01$ мг/мл) у поросят перших годин життя.

Більшість авторів вказують на різке зменшення кількості імуноглобулінів класу $\mathrm{G}$ у перші 30 діб із поступовим їх збільшенням упродовж наступних 2-3 місяців життя тварин (Kadyrov, 1985; Laptenok, 1986; Maslianko, 1999; Maslianko et al., 2002; Antonov et al., 2005; Salyha, 2009; Ratskyi et al., 2010). С дані про зменшення кількості Ig класу $\mathrm{G}$ упродовж першого місяця життя у 48 разів, а згідно з іншими даними, у
70 разів. На думку В. Антонова зі співавт. (Antonov et al., 2005), значні коливання кількості антитіл класу $\mathrm{G}$ насамперед пов'язані з вмістом протеїну загального в сироватці крові та антитіл у молозиві свиноматок. Tizard \& Schubot (2004) вважають, що зниження кількості антитіл класу $\mathrm{G}$ у сироватці крові поросят упродовж першого тижня життя на 22 \% пов'язане зі зменшенням кількості $\operatorname{Ig}$ класу $\mathrm{G}$ у молоці та тим, що синтез власних Ig класу G у поросят незначний через недостатню кількість В-лімфоцитів у крові новонароджених поросят у зв'язку з одноманітністю набору Вклітинних рецепторів, що своєю чергою збільшується лише під дією активної стимуляції бактеріальних антигенів.

Варто відзначити, що тільки у свиней даний клас імуноглобулінів має підкласи $\mathrm{Ig} \mathrm{G}_{1}, \mathrm{Ig} \mathrm{G}_{2 \mathrm{a}}, \mathrm{Ig} \mathrm{G}_{2 \mathrm{~b}}$, Ig $\mathrm{G}_{3}$ та $\mathrm{Ig} \mathrm{G}_{4}$, які кодуються від 8 до 12 імуноглобуліновими генами (Sun \& Hayward, 1998; Butler et al., 2009).

\section{Таблиця 2}

Динаміка вмісту імуноглобулінів класу А у сироватці крові поросят, г/л $(\mathrm{M} \pm \mathrm{m}, \mathrm{n}=15)$

\begin{tabular}{ccc}
\hline Вік поросят, & \multicolumn{2}{c}{ Група поросят } \\
\cline { 2 - 3 } діб & І контрольна & II дослідна \\
\hline 1 & $0,2 \pm 0,01$ & $0,2 \pm 0,01$ \\
5 & $0,1 \pm 0,01$ & $0,1 \pm 0,01$ \\
12 & $0,1 \pm 0,01$ & $0,1 \pm 0,00$ \\
30 & $0,2 \pm 0,01$ & $0,2 \pm 0,01$ \\
\hline
\end{tabular}

Упродовж досліду кількість імуноглобулінів класу А в сироватці крові поросят дослідної групи незначно відрізнялася від такого показника у сироватці крові поросят контрольної групи. Динаміка змін характеризувалась тенденцією до зниження вмісту імуноглобулінів класу А до 12 доби, але на 30 добу даний показник майже не відрізнявся від вихідного значення. Отримані нами дані підтверджують результати досліджень деяких дослідників, але суперечать іншим. Так, згідно 3 результатами досліджень Панікара I. (Panikar et al., 2015), після першого тижня надходження імуноглобулінів класу А з молозивом/молоком зменшується, а до 14 діб відбувається зменшення даного виду імуноглобулінів удвічі (з 0,91 $\pm 0,03$ до 0,42 $\pm 0,02$ мг/мл). Вважають, що саме цей період $\epsilon$ найнебезпечнішим у контамінації слизових оболонок відкритих систем (дихальної та травної) патогенною мікрофлорою.

Припускають, що у період різкого зниження кількості Ig класу G (вік 7 діб) захисну роль, очевидно, беруть на себе $\operatorname{Ig}$ класу $\mathrm{A}$, кількість яких у цей період $\epsilon$ найвищою $(0,91$ мг/мл). У період першого місяця життя зниження кількості Ig класу А в молозиві та молоці свиноматок у 3,8 раза, що пов'язують 3 тим, що материнські антитіла руйнуються, а власні синтезуються в недостатній кількості (у 29 діб - 0,46 мг/мл). За даними (Fedorov \& Verkhovskyi, 1996) відомо, що Ig класу А накопичуються не в крові, а на поверхні слизових оболонок органів травлення і дихання поросят. Саме до клітин поверхні слизових кишечнику прикріпляється більшість Ig класу А, які є в молозиві, а пізніше - в молоці свиноматок. За дани- 
ми Кадирова С. (Kadyrov, 1985), таке зниження відбувається в 3,7 раза.

Встановлено, що антитіла класу А синтезуються безпосередньо в молочній залозі і мають важливе значення в захисті слизової оболонки кишечнику поросят у післямолозивний підсисний період. Материнські специфічні імуноглобуліни класу А зв'язують на поверхні слизової кишечнику більшість антигенів, які потрапляють із кормом та водою. Вважають, що відлучення поросят у місячному віці є стрес-фактором ще й тому, що позбавляє поросят такого важливого фактора імунного захисту, яким $\epsilon$ Ig класу A.

Загалом у новонароджених поросят рівень Ig класу А у сироватці крові є підвищеним $(0,91 \pm 0,03$ мг/мл), $\operatorname{Ig}$ класу M $(0,36 \pm 0,01$ мг/мл) - найнижчим, і в межах нижчої межі норми для даного виду тварин - Ig класу $\mathrm{G}(3,11 \pm 0,01$ мг/мл). Вважають, що рівень Ig класу A в сироватці крові сягає $21 \%$; Ig класу G - $71 \%$, Ig класу М, відповідно, $-8 \%$.

\section{Таблиця 3}

Динаміка вмісту імуноглобуліну класу М у сироватці крові поросят, г/л $(\mathrm{M} \pm \mathrm{m}, \mathrm{n}=15)$

\begin{tabular}{ccc}
\hline Вік поросят, & & Група поросят \\
\cline { 2 - 3 } діб & I контрольна & II дослідна \\
\hline 1 & $0,1 \pm 0,00$ & $0,1 \pm 0,00^{* *}$ \\
5 & $0,4 \pm 0,01$ & $0,4 \pm 0,01^{* *}$ \\
12 & $0,1 \pm 0,01$ & $0,1 \pm 0,01^{* *}$ \\
30 & $0,3 \pm 0,01$ & $0,4 \pm 0,01^{* *}$ \\
\hline
\end{tabular}

Примітка: ступінь вірогідності - ** - P <0,01 порівняно 3 показником у поросят контрольної групи

Упродовж досліду показник вмісту імуноглобуліну класу М у сироватці крові поросят дослідної групи та динаміка його змін протягом досліду майже не відрізнялась від контролю. Отримані нами дані незначно відрізняються від даних, отриманих іншими дослідниками. Так, згідно з результатами дослідження Панікара I. (Panikar et al., 2015), в новонароджених тварин Ig класу М у крові містяться в низьких концентраціях, але впродовж першої доби життя вміст Ig класу М зростає від 8 \% до 15,1\%, набуваючи максимального значення у тварин до кінця першого тижня життя (20\%). Поросята перших днів життя мають достатньо високий рівень власних імуноглобулінів класу $\mathrm{M}(0,54$ мг/мл), які накопичуються в ембріональний період. За даними Антонова В. зі співавт. (Antonov et al., 2005), їх кількість із часом незначно змінюється і коливається у межах 0,48-0,54 мг/мл, не досягаючи показників, характерних для організму дорослих тварин (0,65-0,90 мг/мл). Припускають, що це результат впливу патогенних факторів навколишнього середовища на новонароджений організм та антигенної стимуляції останнього. Згідно $з$ даними інших дослідників - упродовж першого місяця після опоросу в молозиві та молоці свиноматок зменшувалася кількість Ig класу М в 11 разів.

Вищеописана динаміка змін показника імуноглобулінів класу М відображає формування власної імунної відповіді на активну антигенну стимуляцію різного походження, які потрапляють в організм із кор- мом, водою та повітрям уже в перші години після народження. Оскільки Ig класу М за імунної відповіді синтезуються першими, саме в цей час вони частково компенсують нестачу власних високоспецифічних антитіл класів $\mathrm{G}$ та A і зниження кількості материнських (молозивних) Ig класу $\mathrm{G}$ через їх руйнування.

Варто зазначити, що згідно з літературними даними, новонароджені поросята мають незначну кількість власних імуноглобулінів класу М (8,1 \%), яка не залежить від материнських, оскільки антитіла цього класу 3 молозивом майже не надходять у кров новонароджених тварин. Імуноглобуліни цього класу синтезуються у плоді, починаючи з внутрішньоутробного періоду, у відповідь на стимулюючі фактори. Експресія цитоплазматичного Ig класу М на поверхні клітин відіграє вирішальну роль у В-клітинному онтогенезі. Вміст імуноглобулінів класу М у крові новонароджених поросят понад 3 мг/мл вказує на наявність внутрішньоутробної інфекції (Panikar et al., 2013; Panikar \& Nychyk, 2014; Panikar et al., 2015).

\section{Висновки}

Дворазова ін'єкція поросним свиноматкам $10 \%$ розчину клатрохелату Феруму(IV) у дозі 10 мл в поєднанні з ін'єкціями ціанокобаламіну у дозі 500 мкг діючої речовини за 14 та 7 діб до передбачуваного опоросу не впливала негативно на імунний статус новонароджених поросят, забезпечуючи при цьому високий профілактичний ефект щодо ферумодефіцитної анемії.

Динаміка змін кількості імуноглобулінів засвідчує міцний зв'язок між антитілами молозива і молока та антитілами крові поросят. Оскільки поросята народжуються 3 невеликою кількістю власних антитіл виключно класу М, еволюційно сформовані біологічні механізми дозволяють не лише захистити новонароджених поросят материнськими колостральними антитілами класів A i G, а й упродовж усього підсисного періоду захищати молодняк від основних патогенів, які надходять через шлунково-кишковий канал, даючи можливість власній імунній системі тварин поступово адаптуватися до нових умов існування й захищати організм самостійно. Незрілість багатьох ланцюгів протиінфекційного захисту організму новонародженої тварини компенсується пасивною передачею імуноглобулінів через плаценту (Ig класу G) та молоко (Ig класу G, Ig класу A).

\section{Відомості про конфлікт інтересів}

Автори стверджують про відсутність конфлікту інтересів.

\section{References}

Antipov, A. A., \& Zharov, A. V. (2013). Gistologicheskie i morfometricheskie izmeneniya pecheni, pochek, selezenki i limfaticheskih uzlov porosyat pri alimentarnoj zhelezodeficitnoj anemii [Histological and morphometric changes in the liver, kidneys, spleen and lymph nodes of piglets with alimentary iron deficien- 
cy anemia]. Rossijskij veterinarnyj zhurnal. Sel'skohozyajstvennye zhivotnye, 1, 19-21 (in Russian).

Antonov, V. S., Romanko, M. Ye., Mykhailova, S. A., Rudenko, O. P., \& Kovalenko, L. V. (2005). Stan bilkovoho obminu ta pryrodnoi rezystentnosti porosiat pershoho misiatsia zhyttia [The state of protein metabolism and natural resistance of piglets the first month of life]. Veterynarna medytsyna. Mizhvidomchyi tematychnyi naukovyi zbirnyk, 85(1), 63-66 (in Ukrainian).

Antonyak, G. L., Solohub, L. I., Snitynskyi, V. V., \& Babych, N. O. (2006). Zalizo v orhanizmi lyudyny I tvaryn (biohimichni, imunolohichni ta ekolohichni aspekty) [Iron in humans and animals (biochemical, immunological and environmental aspects)]. Lviv (in Ukrainian).

Bland, I., Rooke, J., Bland, V., Sinclair, A., \& Edwards, S. (2003). Appearance of immunoglobulin $G$ in the plasma of piglets following intake of colostrum, with or without a delay in sucking. Animal Science, 77(2), 277-286. doi: 10.1017/S1357729800059014.

Bulter, J., Zhao, Y., \& Sinkora, M. (2009). Immunoglobulins, antibody repertroire and B cell devilopmend. Dev. comp. immunology, 33(3), 321-333. doi: 10.1016/j.dci.2008.06.015.

Butler, J. E., Wertz, N., Deschacht, N., \& Kacskovics, I. (2009). Porcine IgG: structure, genetics, and evolution. Immunogenetics, 61(3), 209-230. doi: 10.1007/s00251008-0336-9.

Derkach, I. M. (2021). Porivnialna efektyvnist ferumvmisnykh likarskykh zasobiv za profilaktyky ferumdefitsytnoi anemii porosiat [Comparative efficacy of iron-containing drugs in the prevention of iron deficiency anemia in piglets]. Scientific Messenger of LNU of Veterinary Medicine and Biotechnologies. Series: Veterinary Sciences, 23(102), 66-71. doi: 10.32718/nvlvet10210 (in Ukrainian).

Dukhnitsky, V. B., Derkach, I. M., Derkach, S. S., Lozovyi, V. M., Kostrub, V. V., Losa, Yu. V., Fritsky, I. O., \& Plutenko, M. O. (2021). Bilkovyi spektr syrovatky krovi porosiat za vplyvu preparativ ferumu [Protein spectrum of piglets' blood serum under the influence of ferrum preparations]. Visnyk Poltavskoi derzhavnoi ahrarnoi akademii, 1, 101-101. doi: 10.31210/visnyk2021.01.31(in Ukrainian).

Dukhnitsky, V. B., Derkach, I. M., Derkach, S. S., Plutenko, M. O., \& Fritsky, I. O. (2019). Influence of iron (IV) clathrochelate complex on quail blood parameters and weight characteristics. Ukrainian Journal of Ecology, 9(3), 126-131. doi: 10.15421/2019 719.

Dukhnitsky, V. B., Derkach, I. M., Plutenko, M. O., Fritsky, I. O., \& Derkach, S. S. (2018). Vyznachennja parametriv gostroi toksychnosti ferumu (IV) na bilyh myshah [Determination of the accumulative toxicity parameters of iron (IV) on white mice]. Ukrainian Journal of Ecology, 8(2), 308-312. doi: 10.15421/2018_343 (in Ukrainian).

Dukhnitsky, V. B., Derkach, I. M., Plutenko, M. O., Fritsky, I. O., \& Derkach, S. S. (2019). Cumulative properties of Iron(IV) clathrochelate in rats [Kumuliatyvni vlastvosti klatrokhelatu Ferumu (IV) dlia bilykh shchuriv]. Visnyk PDAA, 2, 238-246. doi: 10.31210/visnyk2019.02.32 (in Ukrainian).

Dukhnitsky, V. B., Kalachniuk, L.H., Derkach, I. M., Derkach, S. S., Plutenko, M. O., \& Fritsky, I. O. (2020). Iron(IV) hexahydrazide clathrochelate complexes: the chronic toxicity study. Ukrainian Journal of Ecology, 9(3), 18-23. doi: 10.15421/2020_3.

Dukhnitsky, V., Derkach, I., Derkach, S., Fritsky, I., \& Plutenko, M. (2019). Khronichna toksychnist klatrokhelatu Ferumu (IV) dlia bilykh shchuriv [Chronic toxicity of the Iron (IV) clathrochelate complexes for white rats]. Scientific Messenger of LNU of Veterinary Medicine and Biotechnologies. Series: Veterinary Sciences, 21(95), 15-21. doi: 10.32718/nvlvet9503 (in Ukrainian).

Dukhnitsky, V., Derkach, I., Derkach, S., Fritsky, I., \& Plutenko, M. (2020). Doslidzhennia podrazniuvalnoi dii ta alerhennykh vlastyvostei klatrokhelatu Feru$\mathrm{mu}(\mathrm{IV})$ [Investigations of the irritant effect and allergenic properties of Fermat's clatrochelate (IV)]. Scientific Messenger of LNU of Veterinary Medicine and Biotechnologies. Series: Veterinary Sciences, 22(97), 130-135. doi: 10.32718/nvlvet9721 (in Ukrainian).

Dukhnitsky, V., Derkach, I., Derkach, S., Fritsky, I., \& Plutenko, M. (2020). Doslidzhennia protyanemichnoi dii klatrokhelatu Ferumu(IV) na porosiatakh [Study of the antianemic effect of iron (IV) clatrochelate on piglets]. Scientific Messenger of LNU of Veterinary Medicine and Biotechnologies. Series: Veterinary Sciences, 22(99), 107-115. doi: 10.32718/nvlvet9917 (in Ukrainian).

Dukhnitsky, V., Derkach, I., Plutenko, M., Fritsky, I., \& Derkach, S. (2019). Acute toxicity of the iron clathrochelate complexes. Regulatory Mechanisms in Biosystems, 10(3), 276-279. doi: 10.15421/021942.

Fedorov, Yu. N., \& Verkhovskyi, O. A. (1996). Immunodefytsyty domashnykh zhyvotnykh [Immunodeficiencies of pets]. Moskwa (in Russian).

Ganz, T. (2013). Systemic iron homeostasis. Physiological Reviews, 93(4), 1721-1741. doi: 10.1152/physrev.00008.

Gasanov, A. S., Amiov, D. R., Muhutdinova, D. M., Ovsjannikov, A. P., Churna, Z. G., \& Shamsutdinova, N. V. (2020). Anemija i preparaty, primenjaemye pri ee lechenii i profilaktike [Anemia and drugs used in its treatment and prevention]. Kazan' (in Russian).

Havrylin, P. M., Masiuk, D. M., \& Biben, I. A. (2005). Rol i potentsiini mozhlyvosti fiziolohii ta funktsionalnoi morfolohii u vyrishenni problem pidvyshchennia zhyttiezdatnosti produktyvnykh tvaryn [The role and potential of physiology and functional morphology in solving problems of increasing the viability of productive animals]. Dnipropetrovskyi DAU, Visnyk, 2, 6569 (in Ukrainian).

Hryhorev, V. (2006). Dynamyka kletochnykh y humoralnykh faktorov rezystentnosty svynei v rannem postnatalnom ontoheneze [Dynamics of cellular and humoral factors resistance of pigs in early postnatal ontogenesis]. Svynovodstvo [Swine breeding], 1, 28-32 (in Russian).

Kadyrov, S. O. (1985). Immunoglobuliny svin'i: IgG, $\operatorname{IgM}, \operatorname{Ig} \mathrm{A}, \operatorname{sIg} \mathrm{A}$ (vydelenie, ochistka, identifikacija, soderzhanie) [Porcine immunoglobulins: IgG, IgM, 
$\operatorname{Ig} \mathrm{A}, \operatorname{sIg} \mathrm{A}$ (isolation, cleaning, identification, content). Extended abstract of candidate's thesis. VNIIJEV (in Russian).

Karput', I. M., \& Nikoladze, M. G. (2001). Diagnostika i profilaktika alimentarnoj anemii porosjat [Diagnosis and prevention of alimentary anemia of piglets]. Veterinarija, 4, 34-37 (in Russian).

Koliakov, Ya. E. (1986). Veterynarnaia immunolohyia [Veterinary immunology]. Moskwa, Ahropromyzdat (in Russian).

Kryshtoforova, B. V., Lemeshchenko, V. V., \& Stehnei, Zh. H. (2007). Biolohichni osnovy veterynarnoi neonatolohii [Biological bases of veterinary neonatology]. Cymferopol. Terra Tavryka (in Ukrainian).

Laptenok, V. N. (1986). Formirovanie estestvennoj rezistentnosti $\mathrm{v}$ antenatal'nyj i rannij postnatal'nyj periody razvitija svinej i sposoby ee povyshenii [Formation of natural resistance in antenatal and early postnatal periods of development of pigs and ways to increase it]. Extended abstract of candidate's thesis. Zhodino (in Russian).

Levchenko, V. I., Kondrakhin, I. P., \& Vlizlo, V. V. (2012). Vnutrishni khvoroby tvaryn. Chastyna 1 [Internal diseases of animals. Part 1]. Bila Tserkva (in Ukrainian).

Martyshuk, T. V., Gutyj, B. V., Vishchur, O. I., \& Todoriuk, V. B. (2019). Biochemical indices of piglets blood under the action of feed additive "Butaselmevitplus". Ukrainian Journal of Veterinary and Agricultural Sciences, 2(2), 27-30. doi: 10.32718/ujvas2-2.06.

Martyshuk, T.V., Gutyj, B.V., Zhelavskyi, M.M., Midyk. S.V., Fedorchenko, A.M., Todoriuk, V.B., Nahirniak, T.B., Kisera, Ya.V., Sus, H.V., Chemerys, V.A. , Levkivska, N.D., Iglitskej, I.I. (2020). Effect of Butaselmevit-Plus on the immune system of piglets during and after weaning. Ukrainian Journal of Ecology, 10(2), 347-352. doi: 10.15421/2020_106.

Mas'janov, Ju. N. (1992). Immunomorfologija u porosjatsosunov $\mathrm{v}$ norme i pri jeksperimental'noj kolidiaree [Immunomorphology in suckling pigs in normal and experimental colidiarrhea]. Extended abstract of candidate's thesis. Voronezh (in Russian).

Maslianko, R. P. (1999). Osnovy imunobiolohii [Fundamentals of immunobiology]. Lviv, Vertykal (in Ukrainian).

Maslianko, R. P. (2004). Formuvannia peryferychnykh orhaniv imunnoi systemy u tvaryn [Formation of peripheral organs of the immune system in animals Age features of the immune system in animals]. Biolohiia tvaryn, 6(1-2), 39-43 (in Ukrainian).

Maslianko, R. P., \& Kravtsiv, Yu. R. (2000). Vzaiemodiia klityn u protsesi imunohenezu [Interaction of cells in the process of immunogenesis]. Biolohiia tvaryn, 2(1), 48-52 (in Ukrainian).

Maslianko, R. P., Kravtsiv, Yu. R., \& Kravtsiv, Ya. S. (2002). Vikovi osoblyvosti imunnoi systemy u tvaryn [Age features of the immune system in animals]. Biolohiia tvaryn, 4(1-2), 9-15 (in Ukrainian).

Maslianko, R. P., Venhryn, A. V., \& Maslianko, T. R. (2004). Rol imunokompetentnykh klityn u rozvytku imunnoi vidpovidi u tvaryn [The role of immunocom- petent cells in immune development responses in animals]. Naukovo-tekhnichnyi biuleten Instytutu biolohii tvaryn [Scientific and technical bulletin of the Institute of Animal Biology], 5(1-2), 166-169 (in Ukrainian).

Meier, D., \& Kharvy, Dzh. (2007). Veterynarnaia laboratornaia medytsyna: ynterpretatsyia y dyahnostyka: [Veterinary laboratory medicine: interpretation and diagnosis]. Moskwa. Sofyon (in Russian).

Panikar, I. I., Kovalenko, V. L., \& Nosyk, N. I. (2013). Stanovlennia pokaznykiv imunnoho statusu porosiat vikom do dvokh tyzhniv [Formation of indicators of immune status of piglets aged up to two weeks]. Naukovi pratsi NUBIP, 188, 134-141 (in Ukrainian).

Panikar, I., Goralsky, L., \& Kolesnik, N. (2015). Morfolohiia ta imunohistokhimiia orhaniv imunohenezu svynei u period postnatalnoi adaptatsii: monohrafiia [Morphology and immunohistochemistry of pig immunogenesis organs in the period of postnatal adaptation: monograph]. Poltavska derzhavna ahrarna akademiia. Poltava (in Ukrainian).

Panikar, S. A., \& Nychyk, I. I. (2014). Zminy morfolohichnykh pokaznykiv peryferychnoi krovi porosiat pershoho misiatsia zhyttia [Changes in morphological parameters of peripheral blood of piglets the first month of life]. Biolohiia tvaryn, 16(4), 115-120 (in Ukrainian).

Ratskyi, M. I., Vishchur, O. V., \& Kychun, I. V. (2010). Vmist okremykh klasiv imunohlobuliniv u krovi porosiat, khvorykh na kolienterotoksemiiu, ta pry zastosuvanni $\gamma$-hlobuliniv [The content of certain classes of immunoglobulins in the blood of piglets, patients with cholieterotoxemia, and with the use of $\gamma$-globulins]. Biolohiia tvaryn, 12(1), 312-317 (in Ukrainian).

Roit, A., Brostoff, Dzh., \& Meil, D. (2006). Immunolohyia [Immunology]. Moskwa (in Russian).

Salyha, N. O. (2009). Rozvytok ymunnoi systemy u porosiat [Development of the immune system in piglets]. Scientific Messenger of LNU of Veterinary Medicine and Biotechnologies. Series: Biology Sciences, 51, 314 (in Ukrainian).

Shtertsl, Ya., Franek, F., Rzhykhha, Y., Kostka, Y., \& Lants, A. (1992). Voznyknovenye y svoistva neantyhennoho $\gamma$-hlobulyna novorozhdennykh: pervoe poiavlenye estestvennykh antytel y ykh otnoshenye $\mathrm{k}$ bakterytsydnym svoistvam syvorotky [The emergence and properties of non-antigenic $\gamma$-globulin of newborns: the first appearance of natural antibodies and their relationship to the bactericidal properties of serum]. Zhurnal mykrobyolohy, epydemyolohyy, immunobyolohyy, 60-68 (in Russian).

Sun, J., \& Hayward, C. (1998). Antibody repertoire development in fetal and neonatal piglets. Journal Immunology, 168, 291-296.

Tizard, Ia. R., \& Schubot, R. M. (2004). Veterinary immunology: An Introduction. 7th ed. Philadelphia.

Todoriuk, V., Hunchak, V., Gutyj, B., Gufriy, D., Hariv, I., Khomyk, R., \& Vasiv, R. (2018). Preclinical research of the experimental preparation "Ferosel T". Ukrainian Journal of Veterinary and Agricultural Sciences, 1(1), 3-9. doi: 10.32718/ujvas1-1.01. 
Tomyn, S., Shylin, S. I., Bykov, D., Ksenofontov, V., Gumienna-Kontecka, E., Bon, V., \& Fritsky, I. O. (2017). Indefinitely stable iron (IV) cage complexes formed in water by air oxidation. Nature Communications, 8, 1-8. doi: 10.1038/ncomms14099.

Tytarenko, O. (2020). Priama imunna zalezhnist: zdorova svynomatka - mitsne porosia [Direct immune dependence: a healthy sow is a strong piglet]. Tvarynnytstvo $i$ veterynariia, 10, 4-7 (in Ukrainian).
Voronyn, E. S., Petrov, A. M., Serykh, M. M., \& Devryshev, D. A. (2002). Immunolohyia [Immunology]. Moskva. Kolos (in Russian).

Zharov, A. V. (2003). Funktsyonalnaia morfolohyia orhanov ymmunnoi y endokrynnoi system porosiat pry hypotrofyy [Functional morphology of immune and endocrine systems of piglets with malnutrition]. Veterynarnaia patolohyia [Veterinary pathology], 2, 58-59 (in Russian). 